\title{
Pengaruh Kinerja Keuangan Terhadap Closing Price Pada Perusahaan Manufaktur yang Terdaftar di BEI (2013- 2016)
}

\author{
Dewi Siswanti ${ }^{1}$, Ahmad $^{2}$ \\ 1. Dosen Program Studi Komputer Aplikasi Bisnis, Sekolah Tinggi Teknik Malang \\ 2. Dosen Program Studi Magister Manajemen, Universitas Gajayana \\ E-mail: dewisiswanti16@gmail.com
}

\begin{abstract}
The research is intended to find out the influence of financial performance to closing price at manufacturing companies listed in Indonesia stock exchange since 2013-2016. The sub sector manufacturing company selected is plastic and packaging, there are eleven company that totaly company of this categori, with regard sequence and completness of the data financial statements available in the IDX continuosly from 2013-2016. The results showed that 74\% of financial performance variables influence the closing price, while the other $26 \%$ are influenced by other variables.Variable partial most positive effect is NPM, while the mostsmall effect is GPM, two variable which ROE and OPM influence inversely, namely the reduction of the coefficient of the raise the variable closing price.
\end{abstract}

Keywords: financial performance, current ratio, and closing price.

\begin{abstract}
Abstrak
Penelitian ini dimaksudkan untuk mengetahui pengaruh kinerja kuangan terhadap closing price pada perusahaan manufaktur yang terdaftar di Bursa Efek Indonesia sejak tahun 2013-2016. Subsektor perusahaan manufaktur yang dipilih adalah Plastic and packaging, total perusahaan dari kategori ini terdapat sebelas perusahaan, Dengan memperhatikan keruntunan dan kelengkapan data laporan keuangan yang tersedia di IDX secara kontinyu dari 2013-2016. Hasil penelitian menunjukkan bahwa terdapat 74\% variabel kinerja keuangan mempengaruhi closing price, sedangkan 26\% lainnya dipengaruhi oleh variabel lain. Variabel parsial yang paling berpengaruh positif adalah NPM, sementara yang paling kecil pengaruhnya adalah GPM, dua variabel yakni ROE dan OPM memiliki pengaruh berbanding terbalik, yakni pengurangan sebesar koefisien tersebut menaikkan variabel closing price.
\end{abstract}

Kata kunci: kinerja keuangan, current ratio, dan closingprice.

\section{Pendahuluan}

Kinerja keuangan perusahaan dapat diukur dengan variabel rasio keuangan. Walaupun dalam penggunaannya tidak serta merta menjadi variabel utama, karena 
dalam pengukurannya harus memperhatikan variabel manfaat yang dirasakan bagi pengguna. Pada perkembangannya, untuk menganalisis rasio, identik menggunakan empat komponen analisis yakni mengukur likuiditas, solvabilitas, profitabilitas, dan rasio aktivitas (Setiawan, 2014: 97).

Rasio Likuiditas berkenaan dengan kekuatan perusahaan dalam memenuhi kewajiban finansialnya yang sudah jatuh tempo baik kewajiban kepada pihak luar maupun pihak dalam perusahaan, (Pasaribu, 2015:80). Adapun instrumen yang digunakan untuk menganalisis rasio likuiditas, salah satunya adalah menggunakan Current Ratio.Rasio ini menunjukkan perbandingan Current Asset terhadap Current Liabilities, yakni setiap sekian rupiah atau satuan mata uang lain yang digunakan yang menunjukkan posisi kewajiban lancar perusahaan dijamin oleh sekian rupiah/ satuan mata uang lain atas aktiva lancar yang dimiliki perusahaan. Rasio Solvabilitas adalah rasio yang mengukur seberapa besar perusahaan dibiayai dengan kewajiban (Fahmi, 2012:62).Dengan kata lain, jumlah utang yang ditanggung oleh perusahaan lebih dominan dari pada aktivanya. Kondisi demikian menjadi indikator yang memperlihatkan besaran kemampuan perusahaan membayar seluruh kewajibannya. Adapun instrumen yang digunakan untuk mengukur tingkat solvabilitas perusahaan adalah dengan Total Debt to Equity, yakni perbandingan antara Total Liabilities terhadap Total Equity, dengan analisis atas total kewajiban sebesar sekian \% dari total ekuitas. Rasio ini mengukur strategi pendanaan suatu perusahaan bersumber dari hutang dan modal sendiri.

Rasio Profitabilitas adalah rasio untuk menilai kemampuan perusahaan dalam mencari keuntungan, (Kasmir, 2012: 196). Rasio profitabilitas dapat diproyeksikan melalui Return on Investment (ROI) yang memiliki berbagai rasio, beberapa diantaranya adalah Return on Equity dan Profit Margin; Operating Profit Margin dan Net Profit Margin.Return on Equityadalah perbandingan net income terhadap sale. Dimana laba bersih sebesar sekian \% dari total perusahaan adalah sekian \% dari total ekuitas.Profit Margin, adalah perbandingan antara net income terhadap sale, yakni laba bersih adalah sekian $\%$ dari total penjualan, berarti sisanya sebesar sekian $\%$ adalah biaya.

Rasio Aktivitas adalah rasio yang menunjukkan efektif tidaknya perusahaan memberdayakan sejumlah aktiva yang telah dimiliki, (Kasmir, 2011:172). Sehingga 
dapat pula digunakan sebagai petunjuk untuk mengetahui tingkat efisiensi perusahaan untuk memberdayakan dan mengelola sedemikian rupa atas sumber daya yang dimiliki perusahaan. Rasio ini ditunjukkan oleh sejumlah pengukuran pasar, salah satunya dengan Earning per Share (EPS), yakni perbandingan antara Net Income terhadap Average Number of Shares Outstanding. Artinya, laba bersih per lembar saham adalah sekian rupiah/ mata uang yang dpergunakan.

Jumingan (2006:242), menjelaskan bahwa penggunaan informasi kinerja keuangan dapat dilakukan untuk:

1. Mengevaluasi produktivitas kerja organisasi setiap semester atapun tahun program. Dengan ketercapaian prosentase yang telah ditetapkan, akan terlihat sampai dimana kinerja keuangan memainkan perannya. Adapun prosentase ataupun rasio yang masih belum memenuhi harapan bisa menjadi evaluasi dimasa atau periode yang akan datang.

2. Menilai besaran kinerja keuangan setiap unit kerja dalam organisasi dalam mencapai tujuan organisasi. Secara kasat mata, kontribusi tersebut terlihat dari output berupa angka-angka yang tertera, dan bisa diambil kesimpulan berdasarkan prosentase dan diterjemahkan dalam langkah bisnis.

3. Rujukan dalam perumusan kebijakan strategis organisasi dimasa yang akan datang. Dengan mendasarkan pada hasil-hasil keuangan atau rasio-rasio tertentu yang memiliki karakteristik tertentu, dalam hal ini angka-angka yang rendah untuk dijadikan bahan evaluasi kinerja berikutnya.

4. Merumuskan keputusan di tingkat organisasi dan unit-unit kerja organisasi. Secara kasat mata, angka-angka yang terlihat, bisa memberikan gambaran dan penelusuran atas divisi yang berkesesuaian, disertai dengan threatment apa saja yang diperlukan agar memenuhi ketercapaian rasio/ indeks yang diharapkan.

5. Instrumen dalam penetapan kebijakan investasi supaya terjadinya produktivitas organisasi dimasa mendatang. Hal ini senantiasadijadikan sandaran dalam menentukan rasio-rasio keuangan sebagai penentu kinerja keuangan jangka pendek, menengah ataupun panjang. Rasio-rasio ini yang pada laman Bursa Efek Indonesia atau lantai bursa lain menjadi faktor penting yang tidak terpisahkan dalam informasi laporan keuangan. Rasio-rasio ini yang biasanya dijadikan dasar pengambil 
keputusan, baik penanam saham, ataupun para broker/ pialang untuk memberikan saran bagi produk sahamnya.

Dua pendekatan dasar yang lazim digunakan dalam menganalisis dan mempertimbangkan saham adalah adalah analisis fundamental dan teknikal. Analisis teknikal adalah langkah yang mengupayakan estimasi harga saham dengan memperhatikan dan mengevaluasi perubahan harga tersebut di periode sebelumnya, (Stella, 2009). Asumsi yang dijadikan dasar analisis teknikal adalah: (1) Besaran saham merefleksikan datadenga relevan. (2) Data yang diperoleh tersebut merupakan bagian dari adanya perubahan harga pada periode sebelumnya. (3) Pergerakan atas perubahan saham yang dihasilkan berdasarkan struktur data yang spesifik dan terus berulang. Penekanan penelitian ini terhadap closing price sementara ada begitu banyak alat ukur lain yang dapat digunakan untuk mengukur kinerja keuangan karena munculnya sinyal tentang pentingnya closing price tersebut sebagai berikut:

1. Closing price/ harga penutupan merefleksikan semua hal berkaitan dengan data pemasaransecara spesifik yang terjadi pada pasar modal yang terjadi sejak dibukanya pasar modal sampai dimana saat berakhirnya perdagangan saham hari tersebut ditutup.

2. Closing pricemenunjukkan pada tingkat harga yang ditawarkan oleh pemodal untuk melakukan posisi hold, dalam membuka semua informasi dan isu yang mungkin terjadi pada malam hari, pada saat tidak terjadi perdagangan.

3. Data menunjukkan bahwa $90 \%$ ke atasrata-rata pelaku analisis teknikal cenderung menggunakan closing price sebagai input utama dalam informasinya.

Keberhasilan tata kelola perusahaan dapat ditunjukkan dengan adanya kenaikan harga saham. Dengan demikian, investor maupun calon investor menilai bahwa perusahaan berhasil dalam mengelola usahanya (Aditya:2014). Oleh karena tingkat kepercayaan investor maupun calon investor tinggi, maka berdampak pada tingkat investasi yang dilakukan oleh emiten. Kondisi demikian, relevan dengan penelitian Aditya (2014) yang hasilnya bahwa 97\% kinerja keuangan mempengaruhi harga saham perusahaan rokok di Bursa Efek Indonesia. Penelitian serupa oleh Susilowati (2016) menunjukkan bahwa 64,4\% Loan to Deposit Ratio, Return on Asset, Net Profit Margin, dan Debt to Equity Ratio secara bersama-sama mempengaruhi Harga Saham. 
Penelitian yang berbeda dilakukan oleh Adha dan Dewi (2014) yakni secara keseluruhan bahwa EPS, ROE, ROI dan NPM mampu menjelaskan konstrak harga saham sebesar $44.4 \%$ sehingga masih terdapat faktor lain yang dapat mempengaruhi harga saham, misalnya faktor ekonomi negara, politik, kemajuan teknologi dan lainnya.

Penelitian serupa oleh Fitri (2016) yang memuat lima variabel dalam penilaian kinerja keuangan, yakni: Price Earning Ratio, Return On Equity, Debt to Equity Ratio, Total Assets Turnover, dan Current Ratio yang dirasakan tepat untuk mengukur kinerja keuangan dibidang food and beverage. variabilitas variabel harga saham yang dapat dijelaskan oleh variabelPrice Earning Ratio (PER), Return On Equity (ROE), Debt to Equity Ratio (DER), Total Assets Turnover (TATO), dan Current Ratio (CR) sebesar 68.9\%.Dari beberapa penelitian tersebut, maka banyak variabel yang berpengaruh terhadap kinerja keuangan diantaranya Current Ratio, Debt to Equity (DER), Return on Equity (ROE), Gross Profit Margin (GPM), Operating Profit Margin (OPM), Net Profit Margin (NPM), dan Earning per share (EPS) dengan demikian hipotesis dalam penelitian yakni terdapat pengaruh yang positif antara variabel-variabel kinerja keuangan terhadap closing price.

Berdasarkan penelitian terdahulu tersebut, memperkuat keyakinan peneliti untuk mengkaji lebih mendalam tentang Kinerja Keuangan Pada Perusahaan Manufaktur. Hasil penelitian ini diharapkan dapat menambah khasanah pengetahuan baik bagi peneliti, akademisi, praktisi dan masyarakat pada umumnya yang fokus dalam bidang akuntansi dan keuangan.

\section{Metode}

Penelitian yang dilakukan pada delapan perusahaan manufaktur ini merupakan penelitian Eksplanatory Research.Menurut Sugiyono (2005:70) adalah penelitian yang bertujuan menjelaskan kedudukan serta hubungan kausalitas antar variabel-variabel dalam penelitian. Metode analisis data yang digunakan adalah Analisis Regresi Linier Berganda. Uji signifikansi koefisien korelasi bertujuan untuk menjelaskan kekuatan pengaruh antar variabel penelitian. Sebagai alat untuk menggambarkan hubungan antar koefisien korelasi, koefisien determinasi, dan kesalahan baku pendugaan digunakan Analisis Varian atau ANOVA. 
Subsektor perusahaan manufaktur yang dipilih adalah Plastic and packaging, total perusahaan dari kategori ini terdapat sebelas perusahaan. Dengan memperhatikan keruntunan dan kelengkapan data laporan keuangan yang tersedia di IDX secara kontinyu dari 2014-2016, maka diambil tujuh perusahaan yang memenuhi kualifikasi antara lain; (1). Argha Karya Prima Industry, Tbk (AKPI), (2). Asiaplast Industries, Tbk, (APLI), (3). Berlina, Tbk, (BRNA), (4). Lotte Chemical Titan, Tbk, (FPNI), (5). Champion Pacific Indonesia, Tbk, (IGAR), (6). Indopoly Swakarsa Industry, Tbk, (IPOL), (7). Trias Sentosa, Tbk (TRST). Adapun dua kuota tersisa dari penetapa minimal 30 sampel ditetapkan SIMA (Siwani Makmur, Tbk) tahun 2013 dan 2014 untuk memenuhi keruntunan data, sehingga total sampel genap menjadi delapan perusahaan.

Tabel 1.

Distribusi Sampel

\begin{tabular}{|llc|}
\hline Kode & \multicolumn{1}{c|}{ Perusahaan } & Tahun Pengambilan \\
AKPI & Argha Karya Prima Industry & Data \\
APLI & Asiaplast Industries Tbk & $2014-2016$ \\
BRNA & Berlina Tbk & $2014-2016$ \\
FPNI & Lotte Cemical Titan, Tbk & $2014-2016$ \\
IGAR & Champion Pacific Indoensia & $2014-2016$ \\
& Indopoly Swakarsa Industry & $2014-2016$ \\
IPOL & Tbk & $2014-2016$ \\
TRST & Trias Sentosa Tbk & $2014-2016$ \\
SIMA & Siwani Makmur Tbk & $2013-2014$ \\
\hline
\end{tabular}

\section{Sumber: Bursa Efek Indonesia}

Variabel-variabel yang digunakan untuk mengukur pengaruh hubungan rasio terhadap closing price adalah, untuk variabel $\mathrm{X}$ memiliki tujuh variabel,

1. Current Ratio; Current Ratio/ Current Lialibilities (Kategori Rasio Likuiditas) untuk menganalisis apakah setiap Rp. 1 kewajiban lancar yang dijamin oleh setiap besaran aktiva lancar berpengaruh terhadap closing price perusahaan.

2. DER: Debt to Equity = Total Lialibilities/ Total Equity (Kategori Rasio Solvabilitas) yakni setiap total kewajiban dengan besaran yang sudah ditetapkan dari total ekuitas, untuk mengukur besaran dana perusahaan yang bersumber dari hutang dan modal sendiri berpengaruh terhadap closing price perusahaan. 
3. ROE: Return on Equity = Net Income/Average Equity (Kategori Return on Investment) menganlisis apakah setiap besaran net income perusahaan dari total ekuitas berpengaruh terhadap closing price perusahaan.

4. GPM: Gross Profit Margin = Gross Profit/ sale (Kategori Return in Investment) Mengukur apakah perolehan besaran rasio laba kotor dari total penjualan, dengan sisa dari besaran tersebut sebagai biaya berpengaruh terhadap closing price.

5. OPM: Operating Profit Margin = operating profit/ sale (kategori Return on investment). Mengukur apakah perolehan besaran rasio laba operasi dari total penjualan, dengan sisa besaran tersebut sebagai biaya berpengaruh terhadap closing price.

6. NPM: Net Profit Margin = net income/ Sale (Kategori Return on Investment) mengukur apakah perolehan besaran rasio laba bersih dari total penjualan, dengan sisa dari besaran tersebut sebagai biaya berpengaruh terhadap closing price.

7. EPS: Earning per share = Net Income/ Average Number of Shares Outstanding (Kategori Market Measure), mengukur apakah laba bersih per lembar saham berpengaruh terhadap closing price,

8. $\mathrm{Y}=$ Closing price

Gambar 1.

Variabel Penelitian

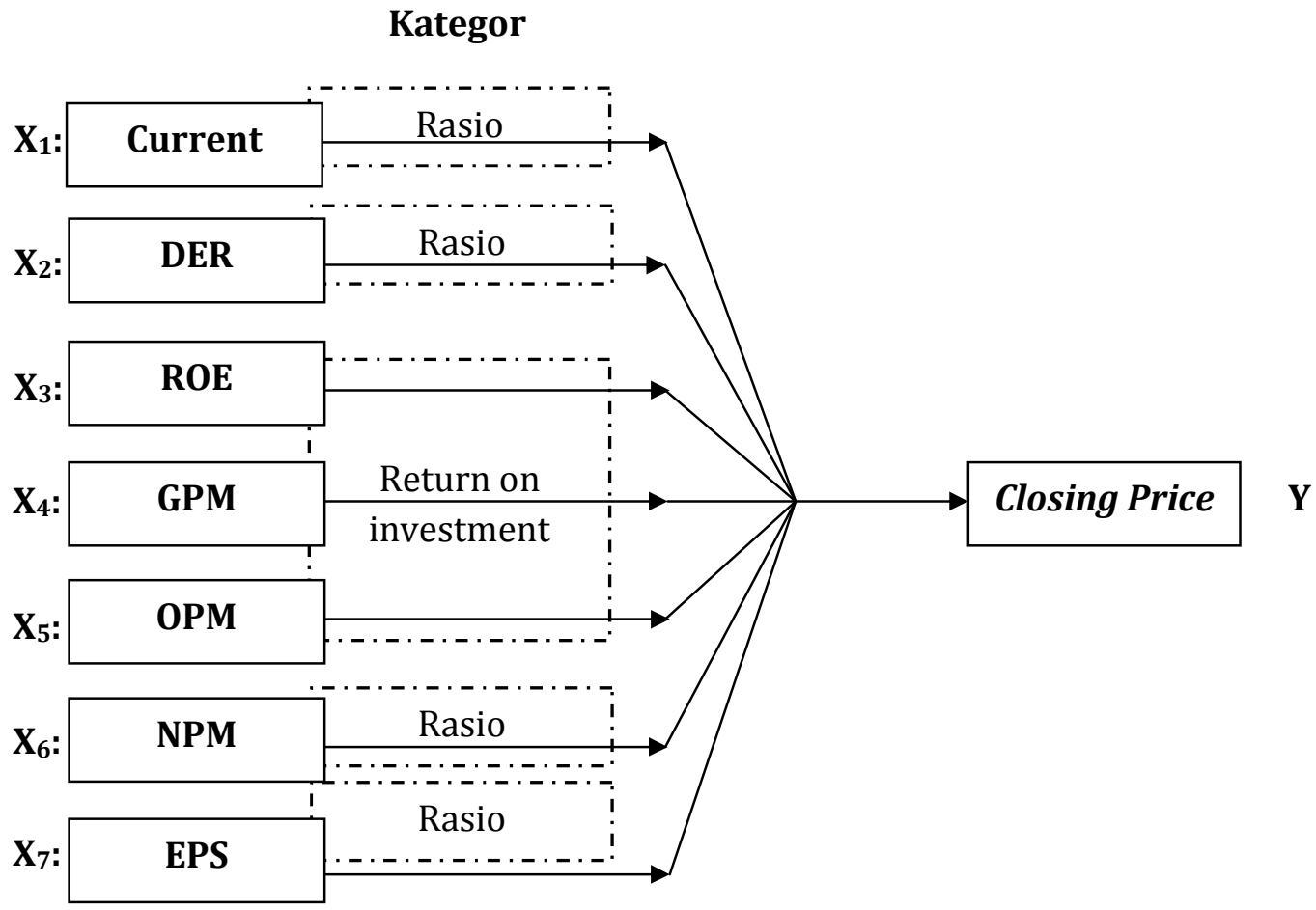


Berikut adalah data yang diperoleh dari Bursa Efek Indonesia

Tabel 2.

\section{Data Variabel}

\begin{tabular}{|c|c|c|c|c|c|c|c|c|}
\hline $\mathrm{N}$ & $\mathrm{CR}\left(\mathrm{X}_{1}\right)$ & $\operatorname{DER}\left(\mathrm{X}_{2}\right)$ & $\operatorname{ROE}\left(\mathrm{X}_{3}\right)$ & GPM $\left(\mathrm{X}_{4}\right)$ & $\mathrm{OPM}\left(\mathrm{X}_{5}\right)$ & NPM $\left(X_{6}\right)$ & $\operatorname{EPS}\left(\mathrm{X}_{7}\right)$ & $\mathrm{CP}(\mathrm{Y})$ \\
\hline 1 & 113.19 & 1.15 & 3.35 & 11.28 & 5.32 & 1.78 & 51.04 & 830 \\
\hline 2 & 287.90 & 0.21 & 4.27 & 14.27 & 5.55 & 3.27 & 6.42 & 81 \\
\hline 3 & 104.67 & 2.64 & 15.56 & 18.12 & 10.62 & 4.53 & 76.68 & 702 \\
\hline 4 & 77.95 & 1.76 & $(6.94)$ & 1.28 & 0.00 & $(1.04)$ & (14.39) & 91 \\
\hline 5 & 412.09 & 0.33 & 20.84 & 14.96 & 10.47 & 7.44 & 56.47 & 315 \\
\hline 6 & 207.78 & 0.76 & 29.42 & 37.40 & 27.42 & 20.51 & 365.16 & 510 \\
\hline 7 & 87.32 & 0.84 & 2.65 & 16.17 & 5.83 & 1.79 & 7.17 & 116 \\
\hline 8 & 146.88 & 0.05 & 0.16 & 12.94 & $(2.09)$ & 2.19 & 7.56 & 465 \\
\hline 9 & 80.62 & 0.99 & 4.39 & 46.76 & 17.88 & 8.75 & 3.11 & 128 \\
\hline 10 & 369.26 & 0.32 & 17.65 & 18.71 & 13.12 & 10.33 & 42.60 & 520 \\
\hline 11 & 123.78 & 0.85 & 1.71 & 8.60 & 4.22 & 1.20 & 10.71 & 380 \\
\hline 12 & 103.06 & 1.60 & 2.50 & 10.83 & 4.45 & 1.37 & 40.67 & 875 \\
\hline 13 & 117.85 & 0.39 & 0.84 & 13.11 & 1.59 & 0.71 & 1.24 & 65 \\
\hline 14 & 114.11 & 1.20 & $(0.86)$ & 17.63 & $(0.19)$ & $(0.56)$ & $(1.55)$ & 727 \\
\hline 15 & 88.22 & 1.43 & 3.10 & 3.90 & 0.00 & 0.65 & 7.85 & 92 \\
\hline 16 & 496.10 & 0.24 & 16.56 & 14.96 & 9.52 & 7.59 & 31.07 & 224 \\
\hline 17 & 227.13 & 0.53 & 11.83 & 32.31 & 17.80 & 11.30 & 158.88 & 925 \\
\hline 18 & 87.83 & 0.83 & 1.74 & 18.80 & 6.07 & 1.33 & 5.21 & 72 \\
\hline 19 & 437.64 & 0.24 & 9.63 & 15.08 & 8.18 & 7.08 & 24.91 & 400 \\
\hline 20 & 130.85 & 0.72 & 1.29 & 8.62 & 3.61 & 1.03 & 9.01 & 310 \\
\hline 21 & 117.00 & 1.49 & 3.77 & 11.53 & 6.92 & 2.62 & 60.74 & 900 \\
\hline 22 & 150.10 & 0.30 & 8.27 & 19.74 & 11.54 & 8.32 & 13.36 & 112 \\
\hline 23 & 105.89 & 1.45 & 2.15 & 16.89 & 2.57 & 1.79 & 21.05 & 1100 \\
\hline 24 & 96.52 & 1.08 & 1.57 & 2.62 & 0.74 & 0.47 & 3.59 & 129 \\
\hline 25 & 465.36 & 0.22 & 16.82 & 18.21 & 13.65 & 10.17 & 41.98 & 520 \\
\hline 26 & 258.82 & 0.54 & 8.90 & 36.59 & 19.93 & 12.49 & 171.30 & 1025 \\
\hline 27 & 98.68 & 0.79 & 10.57 & 22.83 & 8.76 & 11.46 & 10.39 & 136 \\
\hline 28 & 548.50 & 0.21 & 6.87 & 14.57 & 7.32 & 6.02 & 18.78 & 420 \\
\hline 29 & 123.32 & 0.76 & 1.50 & 9.38 & 3.92 & 1.62 & 9.89 & 300 \\
\hline 30 & 103.98 & 0.86 & $(4.40)$ & 9.50 & $(3.06)$ & $(2.98)$ & $(9.46)$ & 840 \\
\hline
\end{tabular}

Sumber: Bursa Efek Indonesia

\section{Hasil dan Pembahasan}

Hasil penelitian menunjukkan bahwa pengaruh variabel bebas terhadap denganclosing price sebesar 0,859, dengan nilai koefisien determinasi sebesar 0,738. Ini 
berarti 73,8\% kinerja keuangan (CR, DER, ROE, GPM, OPM, NPM, dan EPS) mempengaruhiclosing price sedangkan sisanya 26,2 dijelaskan oleh variabel lain.

Tabel 3.

Variables Entered/Removed ${ }^{b}$

\begin{tabular}{|l|l|l|l|}
\hline Model & \multicolumn{1}{|c|}{$\begin{array}{c}\text { Variables } \\
\text { Entered }\end{array}$} & $\begin{array}{c}\text { Variables } \\
\text { Removed }\end{array}$ & Method \\
\hline 1 & & & \\
& $\begin{array}{l}\text { EPS, DER, GPM, } \\
\text { CR, NPM, ROE, } \\
\text { OPM }\end{array}$ & & . Enter \\
& & \\
\hline \multicolumn{2}{|l|}{ a. All requested variables entered. } & \\
\hline \multicolumn{2}{|l|}{ b. Dependent Variable: Y } & \\
\hline
\end{tabular}

Tabel 4.

Model Summary

\begin{tabular}{|l|r|r|r|r|}
\hline Model & $\mathrm{R}$ & R Square & $\begin{array}{c}\text { Adjusted R } \\
\text { Square }\end{array}$ & $\begin{array}{r}\text { Std. Error of } \\
\text { the Estimate }\end{array}$ \\
\hline 1 & $.859 \mathrm{a}$ & .738 & .654 & 182.58733 \\
\hline $\begin{array}{l}\text { a. Predictors: (Constant), EPS, DER, GPM, CR, NPM, } \\
\text { ROE, OPM }\end{array}$ \\
\hline
\end{tabular}

Hasil penelitian tersebut menunjukkan bahwa nilai konstanta negatif artinya terdapat pengaruh negatif variabel independen (CR, DER, ROE, GPM, OPM, NPM, EPS), bila variabel independen turun atau berpengaruh satu satuan maka variabel closing price naik atau terpenuhi. Dengan kata lain, ketetapan, nilai tetap, artinya kalau hasilnya negatif bila variabel pada penelitian tidak ada perubahan akan tetap maka hubungannya negatif.

Berdasarkan hasil penelitian diketahui bahwa variabel yang paling berpengaruh positif adalah NPM, sementara yang paling kecil pengaruhnya adalah GPM, dua variabel yakni ROE dan OPM memiliki pengaruh berbanding terbalik, yakni pengurangan sebesar koefisien tersebut menaikkan variabel closing price. 
Tabel 5.

Coefficients ${ }^{a}$

\begin{tabular}{|c|c|c|c|c|c|c|}
\hline & \multirow[t]{2}{*}{ Model } & \multicolumn{2}{|c|}{$\begin{array}{l}\text { Unstandardized } \\
\text { Coefficients }\end{array}$} & \multirow{2}{*}{\begin{tabular}{|c|}
$\begin{array}{c}\text { Standardized } \\
\text { Coefficients }\end{array}$ \\
Beta \\
\end{tabular}} & \multirow[t]{2}{*}{$\mathrm{T}$} & \multirow[t]{2}{*}{ Sig. } \\
\hline & & B & Std. Error & & & \\
\hline \multirow{8}{*}{1} & (Constant) & -220.649 & 153.844 & & -1.434 & .166 \\
\hline & CR & 148.977 & 60.271 & .564 & 2.472 & .022 \\
\hline & DER & 250.212 & 70.090 & .522 & 3.570 & .002 \\
\hline & ROE & 5895.117 & 1358.453 & -3.517 & -4.340 & .00 \\
\hline & GPM & 844.695 & 613.208 & .751 & 1.378 & .182 \\
\hline & OPM & 2027.285 & 2115.276 & -3.537 & -.958 & .348 \\
\hline & NPM & 3306.144 & 1918.544 & 5.905 & 1.723 & .099 \\
\hline & EPS & 13.839 & 2.110 & 1.183 & 6.560 & .000 \\
\hline
\end{tabular}

Berdasarkan lima tabel diatas, dapat disusun persamaan regresi sebagai berikut:

$$
\begin{aligned}
Y=-220,649+148,977 X_{1} & +250,212 X_{2}-5895,117 X_{3}+844,695 X_{4}-2027,285 X_{4} \\
& +3306,144 X_{5}+13,839 X_{6}
\end{aligned}
$$

Berdasarkan hasil penelitian diketahui bahwa dengan signifikansi 0,000, variabel EPS memiliki signifikansi yang nyata sebesar 6,560, diikuti dengan variabel ROE walaupun dengan kondisi berbanding terbalik sebesar nilai-4.340.

Hasil penelitian menunjukkan bahwa besarankoefisien korelasi kinerja keuangan dengan closing price sebesar 0,859, dengan besaran $\mathrm{R}^{2}$ sebesar 0,738. Ini berarti kemampuan variabel kinerja keuangan (Current Ratio, DER, ROE, GPM, OPM, NPM, dan EPS) dalam menerangkan keragaman variabel closing pricesebesar 73,8\%, sedang sisanya yaitu 26,2 dijelaskan oleh variabel lain. Dengan kata lain, rasio likuiditas yang diproyeksikan oleh Current ratio, rasio solvabilitas yang diproyeksikan oleh DER, Return on Investment yang diproksikan oleh ROE, GPM, OPM, dan NPM, serta Market Measures yang diproyeksikan oleh EPS secara signifikan berpengaruh terhadap Closing price sebesar $73,8 \%$ 
Berdasarkan tabel koefisien dependent variable, dapat disusun persamaan regresi sebagai berikut:

\section{$Y=-220,649+148,977 X_{1}+250,212 X_{2}-5895,117 X_{3}+844,695 X_{4}-2027,285 X_{5}+$ $3306,144 X_{6}+13,839 X_{7}$}

Berdasarkan persamaan regresi tersebut dapat dijelaskan bahwa:

1. Nilai sebesar $-220,649$ adalah konstanta, yang berarti bahwa apabila tidak ada variabel bebas, Current ratio, DER, ROE, GPM, OPM, NPM, EPS yang mempengaruhi, maka besarnya variabel terikat closing price adalah tetap sebesar $-220,649$

2. Nilai sebesar $+148,977$ adalah koefisien regresi variabel bebas current ratio, yang berarti apabila variabel bebas current ratioditingkatkan maka akan terjadi peningkatan pada closing pricedengan syarat variabel bebas lain konstan.

3. Nilai sebesar $+250,212$ adalah koefisien regresi variabel bebas DER, yang berarti apabila variabel bebas DER ditingkatkan maka akan terjadi peningkatan pada closing price dengan syarat variabel bebas lain konstan.

4. Nilai sebesar $-5895,117$ adalah koefisien regresi variabel bebas ROE (X $\left.\mathrm{X}_{3}\right)$, yang berarti apabila variabel bebas ROE $\left(\mathrm{X}_{3}\right)$ diturunkan maka akan terjadi peningkatan pada closing price dengan syarat variabel bebas lain adalah konstan.

5. Nilai sebesar $+844,695$ adalah koefisien regresi variabel bebas GPM $\left(\mathrm{X}_{4}\right)$, yang berarti apabila variabel bebas GPM $\left(\mathrm{X}_{4}\right)$ ditingkatkan maka akan terjadi peningkatan pada closing price dengan syarat variabel bebas lain adalah konstan.

6. Nilai sebesar $-2027,285$ adalah koefisien regresi variabel bebas OPM ( $\left.\mathrm{X}_{5}\right)$, yang berarti apabila variabel bebas OPM $\left(\mathrm{X}_{5}\right)$ diturunkan maka akan terjadi peningkatan pada closing price dengan syarat variabel bebas lain adalah konstan.

7. Nilai sebesar $+3306,144$ adalah koefisien regresi variabel bebas NPM $\left(\mathrm{X}_{6}\right)$, yang berarti apabila variabel bebas NPM $\left(\mathrm{X}_{6}\right)$ ditingkatkan maka akan terjadi peningkatan pada closing price dengan syarat variabel bebas lain adalah konstan.

8. Nilai sebesar $+13,839$ adalah koefisien regresi variabel bebas EPS $\left(\mathrm{X}_{7}\right)$, yang berarti apabila variabel bebas EPS $\left(\mathrm{X}_{7}\right)$ ditingkatkan maka akan terjadi peningkatan pada closing price dengan syarat variabel bebas lain adalah konstan.

Bila dilihat dari nilai unstandardized coefficients, variabel parsial yang paling berpengaruh positif adalan NPM sebesar 3306.144,dengan standard error 
1918.544,yang artinyaperolehan besaran rasio laba bersih dari total penjualan dengan sisa dari besaran tersebut sebagai biaya berpengaruh terhadap closing price, sementara yang paling kecil pengaruhnya adalah GPM sebesar 844.695 artinya perolehan besaran rasio laba kotor dari total penjualan, dengan sisa dari besaran tersebut sebagai biaya berpengaruh paling kecil terhadap closing price, dua variabel yakni ROE dan OPM memiliki pengaruh berbanding terbalik, yakni pengurangan sebesar koefisien tersebut menaikkan variabel closing price. Dengan kata lain, semakin tinggi besaran net income perusahaan dari total ekuitas serta semakin tinggi besaran rasio laba operasi dari total penjualan, dengan sisa besaran tersebut sebagai biaya, berbanding terbalik/ menyebabkan semakin kecilnya closing price.

Akan tetapi, bila dilihat dari taraf signifikansi, variabel EPS dan ROE yang memiliki pengaruh positif terhadap closing price. Berdasarkannilai signifikansi yang tertera pada tabel coefficients diatas, diketahui bahwa dengan signifikansi 0,000, variabel EPS memiliki signifikansi yang nyata sebesar 6,560, diikuti dengan variabel ROE walaupun dengan kondisi berbanding terbalik sebesar -4.340. Signifikansi EPS ini sesuai dengan hasil penelitian Aditya (2014)menunjukkan bahwa penolakan H0 dan penerimaan H1, dan dukungan signifikansi EPS. Signifikansi EPS dan ROE juga didukung oleh hasil penelitian Adha dan Dewi (2014) dengan nilai outer original sample EPS dan ROE tertinggi, yakni EPS 0,9052 dan ROE 0,8949, baru disusul ROI dan NPM. Hal ini bisa dipahami, bagaimana nilai EPS atau laba per lembar saham adalah faktor yang terlihat kasat mata bisa dibandingkan bahkan oleh penanam saham yang paling awam sekalipun. Adapun Return on equity (ROE) juga menjadi pijakan bagi calon pembeli saham perusahaan untuk melihat pengembalian ekuitas yang bisa didapatkan dari perusahaan yang akan dipertimbangkan. Adapun signifikansi ROE ini juga didukung oleh hasil penelitian Fitri dan Yahya (2016) Return On Equity berpengaruh terhadap harga saham.

\section{Simpulan}

Berdasarkan hasil analisis data dan pembahasan penelitian tersebut, maka dapat disimpulkan bahwa kinerja keuangan $86 \%$ berpengaruh secara positif terhadap closing price, dengan nilai koefisien determinasi sebesar 73,8. Hasil penelitian ini menunjukkan 
bahwa variabel-variabel kinerja keuangan mampu menguraikan keragaman closing price sebesar 73,8\%, sedang sisanya yaitu $26,2 \%$ dijelaskan oleh variabel lain. Berdasarkan perhitungan unstandardized coefficient, diperoleh bahwa variabel parsial yang paling berpengaruh secara positif adalah variabel NPM, sementara yang paling kecil pengaruhnya adalah variabel GPM, dan dua variabel lain (ROE dan OPM) memiliki pengaruh berbanding terbalik, dengan adanya pengurangan sebesar koefisien tersebut dapat menaikkan variabel closing price.Variabel EPS dan ROE yang memiliki pengaruh positif terhadap closing price. Dengan besaran pengaruh masing-masing sebesar 6,560 untuk variabel EPS dan -4,340 untuk variabel ROE.

Hasil penelitian tersebut membuka cakrawala berpikir bahwa dalam penelitian dirasa masih sangat terbatas, baik dalam penerapan aspek atau metode pengukuran mungkin dirasakan lebih praktis serta efektif untuk menganalisis closing price, walaupun pada dasarnya $90 \%$ pengambil keputusan saham berpatokan terhadap salah satu alat analisis teknikal ini.Hasil analisis rasio keuangan hanya mampu menjelaskan sebagian kecil pengaruh terhadap closing price, oleh sebab itu perlu dilakukan penelitian lanjutan yang lebih mendalam. Dengan perluasan sampel tidak hanya pada industri plastic and packaging, tapi merambah pada seluruh sub sektor industri manufaktur dan atau menambah jumlah keruntunan waktu pengambilan data, misalnya selama lima tahun terbaru, diharapkan bisa semakin memberikan gambaran utuh mengenai topik ini.

\section{Daftar Pustaka}

Adha, Chinderayi dan Farida Ratna Dewi. 2014. Pengaruh Kinerja Keuangan Terhadap Harga Saham Perusahaan-Perusahaan Produsen Kabel yang Terdaftar di Bursa Efek Indonesia. Jurnal Manajemen dan Organisasi Volume V No 1, April 2014 (Online, diakses tanggal 28 Februari 2018).

Aditya, Rendra Yuli. 2014. Pengaruh Kinerja Keuangan Terhadap Harga Saham Pada Perusahaan Rokok di Bursa Efek Indonesia. Jurnal Ilmu \& Riset Manajemen Volume 3 Nomor 5(Online, diakses tanggal 23 Februari 2018).

Fahmi, Irham. 2012. Analisis Kinerja Keuangan. Bandung: Alfabeta.

Fitri, Sofi Alfia, dan Yahya. 2016. Pengaruh Kinerja Keuangan Terhadap Harga Saham Perusahaan Food and Beverages di BEI. Jurnal Ilmu dan Riset Manajemen Volume 5 Nomor 4, April 2016(Online, diakses tanggal 26 Februari 2018).

Jumingan. 2006. Analisis Laporan Keuangan, Cetakan Pertama. Jakarta: PT Bumi Aksara. 
Kasmir. 2012. Analisis Laporan Keuangan. Jakarta: Rajawali Pers. . 2011. Analisis Laporan Keuangan Cetakan Keempat. Jakarta: Rajawali Pers.

Pasaribu,Aria Masdiana. 2015. Pengaruh Kualitas Auditor, Likuiditas, Solvabilitas, dan Profitabilitas Terhadap Opini Going Concern Pada Sub Sektor Makanan dan Minuman Yang Terdaftar di Bursa Efek Indonesia. Jurnal Riset Akuntansi Keuangan Volume 6 No 2, Agustus 2015 Hal. 80-92.

Setiawan, Temy. 2014. Mahir Akuntansi Akuntansi Biaya dan Manajemen. Jakarta: PT Bhuana Ilmu Populer Kelompok Gramedia.

Stella, 2009. Pengaruh Price to Earning Ratio, Debt to Equity Ratio, Return on Asset dan Price to Book Value Terhadap Harga Pasar Saham. Jurnal Bisnis dan Akuntansi Volume 11 No 2, Agustus 2009, Hlm 97-106.

Sugiyono. 2005. Metode Penelitian Administrasi. Bandung: Alfabeta.

Susilowati, Endang. 2016. Pengaruh Kinerja Keuangan Terhadap Harga Saham. Jurnal Ilmu dan Riset Manajemen Volume 5 Nomor 2, Februari 2016. 